\title{
Launching Agricultural Land Reform in Republic of Moldova
}

John Todd STEWART

\begin{abstract}
The great majority of Moldova's agricultural land was decollectivized and privatized in the period 1995-2000 through the National Land Program, which was primarily financed by the U.S. Government. In this memoir, John Todd Stewart, who was U.S. Ambassador to the Republic of Moldova from 1995 to 1998, describes the origin and development of the "Land" program, which began with a single collective farm and rapidly expanded to all parts of the country.
\end{abstract}

Key-words: Republic of Moldova, agricultural land reform, land privatization.

Agricultural land reform was the most important project undertaken in Republic of Moldova during my tenure as U.S. Ambassador. By the official end of National Land Program (Pământ) in 2000, 836 former collective and state farms had been completely privatized and more than 900,000 Moldovans received land titles. The program was designed and executed by Moldovans, but the U.S. Government provided the necessary financing, some $\$ 100$ million.

\section{Background}

In November 1990, ten months before Moldovan independence, the Moldavian SSR had 2.56 million ha of agricultural land, divided among arable fields (68 percent), orchards and vineyards (18 percent), and pastures (14 percent). Collective farms (kolkhozuri) worked some 57 percent of the total, state farms (sovkhozuri) 29 percent, and agroindustrial complexes 4 percent. The remaining 10 percent was farmed by individuals, either as household plots or rented land in roughly equal measure. There were approximately 1200 collective and state farms with an average of 2000 hectares and 1000 members. Agriculture represented more than 60 percent of the SSR's gross domestic product, and about 40 percent of the labor force was engaged directly in agriculture.

The Parliament of independent Moldova passed in late 1991 a land code envisioning that the 1.2 million collective and state farm members would be entitled to receive equal shares of the farms' land and other assets in private ownership. This meant, however, that each farm member would be entitled to an average of only 1.5 hectares, a parcel too small to be farmed economically. Opponents seized on this fact, and little decollectivization took place due to opposition from some farm managers, periodic legislative roadblocks, and the lack of a coordinated national strategy for the calculation and distribution of land shares. 
By the middle of the decade, less than 10 percent of the rural population had broken away from the collective farm system, and the old collectives were stagnating, unable to compete with Western agriculture. Moldovan and American observers were concerned about this lack of progress because they recognized that economic growth could be spurred by increased productivity in agriculture and the movement of redundant workers into other sectors of the economy.

\section{Origins of the "Land" Program}

Shortly before my arrival in Chisinau in October 1995, a team headed by Vincent Morabito from the East-West Management Institute (EWMI), a U.S. nonprofit and USAID contractor, came to Moldova to assist newly privatized firms in organizing to meet the demands of a market economy. The Center for Private Business Reform (CPBR), which the EWMI representatives founded, received applications from a number of businesses, including - to their surprise - the Maiac collective farm near the village of Nisporeni. The new leadership of Maiac was determined to decollectivize as they had determined that the old enterprise could not function well enough to meet the demands of the Moldovan and world economies. For this reason, they sought the assistance of CPBR/ EWMI in breaking up the farm into economically viable units.

The EWMI team welcomed the Maiac request because they were familiar with the privatization methodology developed by Dr. Vasile Uzun, a Moldovanborn academic then active in Russia. According to Dr. Uzun's “leader-entrepreneur" concept, members of a collective or state farm who didn't wish to physically farm their land could lease (or perhaps later sell) their parcels and their shares of the farm's other assets to a "leader-entrepreneur" who would put together an economically viable operation by obtaining land from inactive farm members. The pool of such persons was potentially large since almost half the members of the average farm were retirees, who would receive rent payments to supplement whatever pensions they might receive from the government. Active workers uninterested in farming could use their rent payments or sales proceeds to launch careers in other sectors of the economy.

Moldovan legislation, both the Land Code and subsequent laws, permitted this approach, but there were complications to overcome. The first was that a farm member was legally entitled to receive his or her proportionate share of each type of the farm's land - cropland, orchards, and vineyards - totaling 1.5 ha on an average farm. Division on this formula would require a considerable amount of surveying - and discussion about what each parcel was worth compared to others, taking into account location and soil quality.

Fortunately, a team headed by Robert Cemovitch from the U.S. company Booz-Allen \& Hamilton (BA\&H) had already begun working at this time in 
Moldova to support land privatization under a USAID contract. The team's focus had been on urban land, primarily parcels attached to recently privatized firms. However, when offered the opportunity, they readily turned to agricultural land privatization, beginning with the Maiac farm.

When the EWMI and BA\&H party chiefs explained this opportunity to me in late 1995, I was enthusiastic. For some time the U.S. Government had been looking for ways to decollectivize agriculture in the former Soviet Union, but no approach had attracted much support. A successful land privatization program in Moldova, a small scale but potentially significant testing ground, could offer a promising approach for the rest of the former USSR.

The Maiac farm seemed a perfect place to start. Its leadership, and apparently a great majority of its membership, were anxious to move forward. Another element, true in all Moldovan collective and state farms, was the fact that collectivization had only occurred in the late 1940s. Many farm families had positive memories of private farms in pre-Soviet times. I remember asking one Maiac farm leader if he knew the location of his family's farm before collectivization. He replied, "Yes, I know. It doesn't make any difference, of course, but I know."

Dr. Uzun's methodology appeared to work well at the Maiac farm. The land was surveyed and a consensus developed approving the division of land into parcels. Farm members were allocated an equal number of bidding points enabling them to bid, individually or collectively, on each parcel. Ten leaderentrepreneurs were able to attract farm members willing to assign their bidding points to these leaders in exchange for future rental payments or some other compensation. The leaders then negotiated among themselves a division of the farm, taking into account the type of land, its location, the soil quality, and their relative number of bidding points. I attended the auction on June 30,1996, which formalized the agreement breaking up Maiac into 10 new enterprises.

\section{Land Reform Gains Political Support}

In a sign of support from the Moldovan Government, the June 30 auction was attended by Deputy Prime Minister Valeriu Bulgari, and Privatization Minister Ceslav Ciobanu, who were already discussing with us the replication of the Nisporeni model in 70-odd more collective or state farms throughout the country. Then on October 2, the Constitutional Court of Moldova declared unconstitutional the provisions of the existing law that suspended until 2001 the right of an individual owner to sell his or her land and restricted the allocation of land to individuals by collective and state farms to the period November 1 to March 1 of each year. The decision was only tacitly accepted by the ruling Democratic Agrar- 
ian Party, but Moldovan President Mircea Snegur campaigned for reelection that autumn on a platform firmly embracing the privatization of agricultural land.

Snegur's primary challenger, Speaker of Parliament Petru Lucinschi, also endorsed continued land privatization, albeit in somewhat equivocal terms. For example, he recognized that land is now a saleable commodity but warned that "we cannot permit the land to fall into the hands of the rich people of this country or those beyond our borders who are not known to us..." Nevertheless, following his victory, President-elect Lucinschi traveled to the former Maiac farm in Nisporeni on December 10 to participate in the ceremonial presentation of the first batch of land titles to members of the former collective. Many of the recipients were in tears, and when one woman stood staring at her certificate, the President-elect told her in a stage whisper, "Put it behind the icon," the traditional place for valuables in a rural home.

At the ceremony, which received extensive television coverage, Lucinschi announced his full support for extending the Nisporeni model to some 70 farms in all regions of Moldova. This extension had been underway for some months with the farms selected from 150 applicants, based largely on their members' strong interest in decollectivization. In October EWMI and BA\&H conducted an extensive training session attended by Deputy Prime Minister Bulgari for nine teams who would work with the farms in their regions of the country. It was hoped that these farms would serve in turn as models for the remainder of Moldova's remaining 1000-odd collective and state farms.

\section{Land Privatization Moves Forward with New Government}

Following his inauguration on January 1997, President Lucinschi reiterated his intention to move forward with agricultural land reform, including legislation establishing modalities for the sale of agricultural land. Parliament was slow to move legislation legitimizing land sales, but Deputy Prime Minister Bulgari ruled that registration and titling of newly privatized land would proceed on the basis of the decentralized - and much more rapid - procedures BA\&H proposed. At a televised meeting July 17 with me and EWMI and BA\&H representatives, Lucinschi expressed pleasure with the progress made in breaking up the 70 farms and repeated his determination to move forward rapidly. Eight days later Bulgari wrote to me to praise the progress made at the 70 farms and requested that the project be expanded the following year to 500 or more farms, constituting some 70 percent of rural land. In August - spurred by presidential prodding, the previous year's ruling of the Constitutional Court, and a World Bank loan conditioned on this step - Parliament finally passed legislation permitting the sale of land and ratifying the decentralized procedures for surveying, registering, and titling that had been adopted administratively. 
Moldovan officials recognized, of course, that land privatization, while a necessary step, was hardly sufficient for the prosperity of the country's agricultural sector. The new agricultural enterprises would require credit at affordable rates, extension services to improve their productivity, and assistance in marketing their products abroad. In soliciting foreign assistance, the government envisioned that the United States would initially concentrate on privatization, including titling and enterprise formation, while the World Bank and the European Union would focus on the post-privatization challenges.

During 1997 I participated in a number of land-titling ceremonies at former collective farms. The most memorable occurred on November 7, the 80th anniversary of the Bolshevik Revolution, when I accompanied President Lucinschi to his home town, Radulenii Vechi, in Falesti Raion, where he distributed land titles to members of the former collective there. The President told his fellow townspeople, "We have started a new era, a new life, and there is no way back. Everything can be achieved if you work hard and willingly." With a nod to the date's significance, I responded in my remarks, "Mr. President, today you are really giving land to the people!" Applause erupted from the audience.

\section{The National "Land" Program}

With Parliamentary elections only weeks away, President Lucinschi presided over a four-hour seminar on February 14, 1998, to assess the results to date of land privatization. I joined Prime Minister Ion Ciubuc and other officials to hear detailed commentaries from some 500 leaders and local officials representing the 73 former collective and state farms broken up in the project's first two phases. Almost all speakers appeared pleased with the program, but many called on the government to provide more post-privatization assistance better financing, farm equipment, seeds and fertilizer, marketing aid, etc. The Moldovan officials responded with surprising directness, given the proximity of the elections, telling farmers that they would have to arrange their own inputs, financing, and marketing in Moldova's new economy. However, a leading banker announced that her institution would reduce the interest rate on crop loans from 28 to 22 percent in view of the fall in the country's inflation rate to 11 percent in 1997.

On March 14, just before election day, President Lucinschi convoked a nationally televised meeting of some 1500 farm leaders, regional executives, mayors, and land surveyors in Chisinau's opera house to launch the decisive phase of land privatization, christened the National "Land" Program, which was intended to break up and privatize a further 550-odd farms over the next 15 months. The meeting was conducted by Prime Minister Ion Ciubuc under 
a banner reading "1998 - Year of the Private Farmer" with the President, the Prime Minister, six other Moldovan officials, and I arrayed across the stage. I was assured that all 35 raion chief executives were present, "even those who didn't want to be"- an allusion to some foot-dragging by a handful of executives. Over 400 farms were represented at the meeting, and 625 farms had applied to participate in the program, each receiving an information packet with detailed step-by-step instructions on the process and sample contracts to be signed by the farm leaders and the Ministry of Privatization. A succession of speakers from all parts of Moldova praised the program and thanked the U.S. Government for its support. Closing the meeting, President Lucinschi stressed the need to seize the moment and carry agricultural reform to its conclusion in 1998.

The parliamentary elections on March 22 resulted in the formation of a pro-reform government, again headed by Prime Minister Ciubuc, that included in its work program measures "to finish the land reform program (i.e., privatize all agricultural land) and create a real estate market through laws governing the sale of land, etc." The way seemed clear for full implementation of the National "Land" Program.

\section{"Land" Methodology}

While relatively simple in concept, the "Land" methodology presented daunting challenges.

The first tasks were to explain the program to local officials (mayors, land commissioners, etc.) and the program's farmer beneficiaries and then to promote the emergence of leader-entrepreneurs in the former collectives who would induce their fellow members to join them in forming new enterprises. For this purpose, EWMI/CPBR, which had only a few American team members, assembled a staff of roughly 220 Moldovan professionals - accountants, economists, agronomists, lawyers, communication specialists, etc. -located in Chisinau and 10 regional centers. At the farm level these professionals and additional temporary staff worked with the mayor, leader-entrepreneurs, and individuals to explain the program and help aspiring leader-entrepreneurs to attract other farm members to lease, sell or barter their land in order to create an economically viable enterprise that could be ratified in the auction breaking up the old collective.

The surveying and titling requirements were monumental. It was necessary to survey over 1.5 million ha of agricultural land, create more than 2.4 million land parcels, and issue titles to their owners. New laws and regulations had to be developed and approved by the government - and, in some 
cases, Parliament - and communicated effectively to regional and local officials. Operating with just a handful of American expatriates, BA\&H engaged a staff of Moldovan professionals in their Chisinau headquarters to develop the new laws and regulations for consideration by the government. This staff then eventually helped to establish and train over 50 private firms to conduct the survey work throughout Moldova. A vital component of BA\&H's work was public information: the preparation of written materials to farm members and local officials about the titling procedures and the rights of the new owners. This material was supplemented by visits to villages by public education teams. All this work, including payments to the surveyors, was financed by the U.S. Government.

A final complication resulted from the extensive debts of the old collectives, which posed a bar to their liquidation. Working with the government, EWMI/ CPBR's Moldovan lawyers helped develop legislation that liquidated these debts by transferring the farms' social assets (schools, etc.) to the government and exchanging private debts for tax exemptions. No part of the debts was inherited by the new successor enterprises.

\section{Conclusion}

I departed Moldova in August 1998, well before the "Land" program formally ended in December 2000. By the conclusion of the program 836 collective and state farms had completed the privatization process and were liquidated. More than 900,000 persons received land titles, and some 588,000 new farming enterprises were registered. Forty-one percent of the new farms were over 500 ha in size, 28 percent between 100 and 500 ha, and 6 percent between 1 and 99 ha. The remaining 25 percent of farms were managed by persons farming individually, or with family and friends, in varying sizes. The great majority of the new farms were formed by leasing recently privatized land from its new owners, but land purchases also played a significant role in consolidation.

The U.S. Government was the principal financial backer of the "Land" program, contributing some 100 million dollars through EWMI/CPBR and $\mathrm{BA} \& \mathrm{H}$ over the course of the program. Washington made this commitment because of the strong support for land reform by the Moldovan Government, confidence in the USAID contractors to carry out the program, and the hope that success in Moldova would serve as a model for similar programs elsewhere in the former Soviet Union.

Neither the Moldovan authorities, the U.S. Embassy, the USAID contractors, nor Washington agencies were under any illusion that land reform would, by itself, create a prosperous agricultural economy in Moldova. Privatization 
was a necessary step, but the new farm leaders would face the daunting task of raising and marketing crops and livestock that would sell profitably on the demanding world market. Some would fail, but others would enjoy the rewards that successful entrepreneurship brings to their enterprises and the country.

\section{Rezumat}

Marea majoritate a terenurilor agricole din Moldova au fost decollectivizate și privatizate în perioada 1995-2000 prin intermediul Programului Național Pământ, care a fost finanțat de către Guvernul SUA. În aceast articol, John Todd Stewart, care a fost ambasadorul SUA în Republica Moldova din 1995 până în 1998, descrie originea și dezvoltarea programului „Pământ”, care a început cu o asociație colectivă și s-a extins rapid în toate părțile republicii.

Cuvinte-cheie: Republica Moldova, reforma agriculturii, privatizarea pământului. 